\title{
VIEWPOINTS
}

\section{Good is Good for Everybody: \\ The Similarities of Corporate Governance across Faiths}

\begin{abstract}
Kurt Lieberman*
In many ways humanity is in a better place than it ever has been. From a material standpoint, the last few decades have seen immense numbers of people move out of poverty. For example, China alone has moved hundreds of millions out of poverty. People are connected through technology and travel more than ever before. Global travel occurs routinely for many business people. Social media connections are global and people can instantly know about events occurring in far-flung corners of the world. Internet connections allow phone and video calls at little to no expense.

Yet, large numbers of people are fearful and even depressed. They are dissatisfied with part or all of their lives. In developed countries, there are concerns about economic inequality and 'rigged' systems. In emerging and under-developed countries there are concerns about bad and non-representative governments, where leaders can accumulate wealth for themselves at the expense of the people. The recent "Panama Papers" incident highlights these realities as people see government leaders hiding ill-gotten funds in secret locations. The result has been elevated anxiety around the world.

Increasingly, people are targeting their anger and frustration at governments and businesses, with people having lost trust and faith in both these institutions. Perceptions of crony capitalism and outright corruption have stained these institutions. Even when these institutions intend to do good things, the loss of trust and faith in their motivations can, like the rust that forms on corroded pipes, make them less effective. Corroded trust and faith is a large and growing problem, particularly as governments and companies are the ones with the potential to fix many of the issues impacting on people.

Good governance is like stainless steel. Stainless steel is impervious to corrosion. If institutions can strengthen their governance, the trust and faith in these organisations will return and grow over time. Further, the existence of good governance will help prevent future corrosion of trust and faith.
\end{abstract}


People around the world turn to their religion on questions of faith and ethics. Religion is the source of stainless steel in our daily lives. Perhaps, therefore, religion can use its values and ethics to prevent further corrosion, and even reverse prior corrosion, within institutions. Since there are multiple religions, a critical issue here is the degree to which religions can collectively provide cohesive guidance on governance. To the extent that different religions have divergent views, their anti-corrosive power might be diffused and less impactful.

Nevertheless, methods of corporate governance based on religious teachings show a high degree of similarity and, very importantly, a very cohesive set of desired company behaviours. Simply put: good governance is basically the same for everybody, everywhere.

It is easy to talk about good governance, yet historically we have not had a clear prescriptive view of what this concept entails. There has not, for example, been a global consensus on good governance standards. A starting point for an investigation of the cohesiveness of religious guidance on governance needs to include a governance model.

In this regard, Magni Global Asset Management LLC is an American research and asset management company focused on governance. ${ }^{1}$ Magni assesses countries on the degree to which they adhere to the good governance and economic concepts most conducive to sustainable and equitable growth. Magni also applies these standards to companies, assessing the degree to which they behave in a manner consistent with good governance. Magni has three corporate governance models: one for secular uses, one for Catholicism, and one for Islam. A comparison of these three corporate governance models demonstrates a high degree of similarity and cohesiveness in desired company behaviours.

\section{Understanding the Three Corporate Governance Models}

To understand the commonalities and differences between the three corporate governance models, they need to be explained. The secular corporate governance model is derived from the work of the Caux Round Table ${ }^{2}$ and its Global Executive Director, Stephen Young. ${ }^{3}$ The secular model is called "Magni Sustainable Value Creation" and covers thirty-five topics across the major stakeholders of a company. ${ }^{4}$

The Catholic corporate governance model is called Catholic Social Teaching and starts with the "Compendium of Social Doctrine of the Church." Catholic guidance on companies has four key themes: human dignity, subsidiarity, solidarity, and the universal destination of goods. These themes provide a moral compass for Catholic corporate governance. 
The Islamic corporate governance model is called Islamic Stewardship and starts with guidance from the Qur' an and Hadith regarding the five values most relevant to companies and investing: Amanah (trust), Adl (justice), Shurah (consultation), Ijtihad (juristic reasoning), and Rahmah (mercy). In addition, Shari'ah has five Maqasid, broad overarching purposes, that are relevant to companies and investing. ${ }^{6}$ Collectively, these five values and five overarching purposes provide a moral compass to Islamic corporate governance.

\section{Similarity of Corporate Governance Models}

When the above three corporate governance models are compared, twenty-four of the thirty-five topics from the secular model (more than 68\%) are identical across the three models. The remaining eleven have similar, though not identical, wording in the Catholic and Islamic models. While the differences in wording are important in the context of each religion, companies being assessed on these eleven topics would receive similar scores from all three models.

For example, all three models expect companies to be concerned with the skills and capabilities of their employees. The secular model focuses on the programmes a company uses to encourage and reward employee growth in these areas. The Catholic model, on the other hand, applies the principle of human dignity to ensure that companies maximise opportunities for employees. The Islamic model applies the Maqasid on promoting knowledge and thoughtful conduct to argue that companies help and support the intellectual growth of their employees. People assessing companies from a secular perspective would find this 'broadening' from the Catholic and Islamic models to be a good idea, but not necessarily something required of companies. Further, Catholics would find the concept of intellectual growth as good, while Muslims would find the idea of maximising opportunities as good. Even with the additional topics, companies are likely to score similarly across the three models.

The Catholic model adds six topics to the thirty-five in the secular model. Human dignity creates the expectation that companies offer commensurate quality for the price they charge. Subsidiarity creates the expectation that companies decentralise decision making where practical and appropriate. Solidarity creates the expectation that companies should: (1) achieve the loyalty of their employees, (2) balance long term and short term priorities, (3) avoid unfairly imposing their interests on their supply chain, and (4) be good stewards of their power and influence. People assessing companies from a secular perspective, as well as Muslims using the Islamic model, would find these additional topics to be good ideas, but not necessarily required of companies.

The Islamic model adds three topics to the thirty-five in the secular model. 
Companies must have and honour warranties to fulfill their Amanah obligations. The products and services of companies need to be beneficial and not cause harm or require illicit activities per the Maqasid on promoting life and the Maqasid on promoting good values and human nature. Companies must be pro-family in their employee and community development programmes per the Maqasid on promoting life. Similar to the prior discussion, people assessing companies from a secular and Catholic perspective would find the additional topics to be good ideas, but not necessarily required of companies.

\section{Implications for Muslims and all of Mankind}

The Qur'an intends all Muslims to be happy. To make the world better and more joyful, we need to build our institutions with the stainless steel available from Islamic guidance on good governance. There are now standards that can be used to assess the quality of governance in both countries and companies, providing existing institutions with a path to better governance. Improving governance can reduce, and possibly even reverse, the corrosion of trust. Moreover, religious people around the world can now work together to build better institutions through good governance, confident that they are providing cohesive direction.

\section{Notes}

* Kurt Lieberman is the CEO of Magni, a US based research and asset management firm. Mr. Lieberman works to improve communities through social service, inner-city education, and welfare organizations.

1. More information on Magni Global Asset Management can be found at www. magniglobal.com. The author of this article is Kurt Lieberman, Chief Executive Officer and Chief Research Officer of Magni. For reference, Kurt Lieberman was born and raised a Unitarian.

2. The Caux Round Table is an international network of experienced business leaders who believe that capitalism is a force for good in the world (www. cauxroundtable.org).

3. Stephen Young is also considered one of the twenty-three most important people in the corporate social responsibility movement per Sandra Waddock's book "The Difference Makers".

4. Magni Sustainable Value Creation uses the standard stakeholders: customers, employees, owners, suppliers, competitors, and community.

5. See www.vatican.va.

6. These are: respect for and promotion of life; respect for and promotion of good values and human morality (religion and civilisation or din); respect for and promotion of knowledge and thoughtful conduct; respect for and promotion of property; respect for and promotion of family and progeny. 